\title{
The insulin sensitiser metformin regulates chicken Sertoli and germ cell populations
}

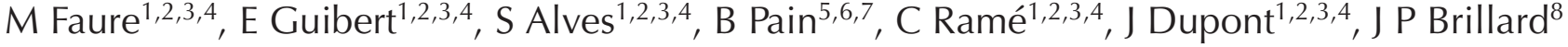 \\ and P Froment ${ }^{1,2,3,4}$ \\ ${ }^{1}$ INRA, UMR85 Physiologie de la Reproduction et des Comportements, F-37380 Nouzilly, France, ${ }^{2}$ CNRS, \\ UMR7247 Physiologie de la Reproduction et des Comportements, F-37380 Nouzilly, France, ${ }^{3}$ Université François \\ Rabelais de Tours, F-37041 Tours, France, ${ }^{4}$ IFCE, F-37380 Nouzilly, France, ${ }^{5}$ INSERM, UMR846, Sterm Cell and \\ Brain Research Institute, Bron, France, ${ }^{6}$ INRA, USC1361, Bron, France, ${ }^{7}$ Université de Lyon, Lyon 1, UMR846, Lyon, \\ France and ${ }^{8}$ FERTIL'AVI, 37360 Rouziers de Touraine, France
}

Correspondence should be addressed to P Froment; Email: pfroment@tours.inra.fr

\begin{abstract}
Metformin, an insulin sensitiser from the biguanide family of molecules, is used for the treatment of insulin resistance in type 2 diabetes individuals. It increases peripheral glucose uptake and may reduce food intake. Based on the tight link between metabolism and fertility, we investigated the role of metformin on testicular function using in vitro culture of Sertoli cells and seminiferous tubules, complemented by in vivo data obtained following metformin administration to prepubertal chickens. In vitro, metformin treatment reduced Sertoli cell proliferation without inducing apoptosis and morphological changes. The metabolism of Sertoli cells was affected because lactate secretion by Sertoli cells increased approximately twofold and intracellular free ATP was negatively impacted. Two important pathways regulating proliferation and metabolism in Sertoli cells were assayed. Metformin exposure was not associated with an increased phosphorylation of AKT or ERK. There was a $90 \%$ reduction in the proportion of proliferating germ cells after a 96-h exposure of seminiferous tubule cultures to metformin. In vivo, 6-week-old chickens treated with metformin for 3 weeks exhibited reduced testicular weight and a $50 \%$ decrease in testosterone levels. The expression of a marker of undifferentiated germ cells was unchanged in contrast to the decrease in expression of 'protamine', a marker of differentiated germ cells. In conclusion, these results suggest that metformin affects the testicular energy content and the proliferative ability of Sertoli and germ cells. Reproduction (2016) 151 527-538
\end{abstract}

\section{Introduction}

In many species, metabolism regulates several functions such as nutrition, growth, thermogenesis and reproduction. A tight link exists between nutrition and fertility (Hocking 1987, Schneider 2004). For example, if cellular energy balance is positive, such as in the case of obesity and insulin resistance, there is a reduction in reproductive ability in both sexes (Chou et al. 2014). Abnormal amenorrhoea in females is the first sign of these adverse effects (Franks et al. 1996), and in males there is a decrease in sperm production usually associated with altered sex hormone secretion (Rato et al. 2014). One of the most frequent causes of female infertility is polycystic ovary syndrome (PCOS), which affects $5-10 \%$ of women of reproductive age and is frequently associated with insulin resistance. PCOS is characterised by hyperandrogenia, cysts and a chronic absence of ovulation. Similarly, obese men are often associated with hypotestosteronaemia (Pasquali 2006), and perturbed sexual maturity and gonadal activity. The domesticated chicken has been extensively selected for high growth rates and muscle development since 1950 (Havenstein et al. 2003). Chickens are naturally hyperglycaemic $(2 \mathrm{~g} / \mathrm{L})$ and are 'relatively' insulin resistant (Dupont et al. 2012), making it an interesting model for studies focusing on type 2 diabetes in humans or obesity (Walzem et al. 2014). Indeed, chickens mimic the early stage of type 2 diabetes in humans, as observed by both hyperglycaemia (up to $200 \mathrm{mg} / \mathrm{dL}$ in the fasting state) and resistance to exogenous insulin (Ji et al. 2012). Several metabolic genes involved in obesity or diabetes are conserved with humans in contrast to rodents. In addition, chickens produce de novo lipids from the liver as in humans (Ji et al. 2014).

However, the chicken presents an interesting peculiarity in that the time required to produce spermatozoa is notably shorter in comparison with others vertebrates (duration of the spermatogenetic process was on 14 days vs 35 and 64 days in the mouse and human respectively; Brillard \& de Reviers 1981). The chick testes, in contrast to those of most mammals, are internally located in the abdominal cavity. Avian testes share a similar histology with mammalian interstitial androgen-producing Leydig 
cells, and Sertoli and germ cells within the seminiferous tubules. Sertoli cells have a similar function to support, nourish, and protect germ cells, and are required for the appropriate differentiation of germ cells. The number of Sertoli cells will determine the number of germ cells and, therefore, the number of spermatozoa produced (de Reviers et al. 1980, Petersen \& Soder 2006). To carry out these functions correctly, it is necessary that Sertoli cells are sensitive to external signals such as systemic energy levels, hormones, and exogenous factors, and that they are able to transmit this information to germ cells through the modification of the secretion of factors crucial for spermatogenesis.

Metformin, an insulin sensitiser, is known to mimic food restriction and may modulate male fertility. Tartarin et al. (2012) showed a decrease in testis size by 1 day postpartum after embryonic exposure of mice to metformin. Moreover, it appears that metformin decreases testosterone secretion in human and mouse testes in organotypic culture. However, there is evidence that metformin does not negatively impact the quality of fresh mouse spermatozoa, and its presence in cryopreservation protocols may induce a benefit for the postthaw quality of frozen semen (Bertoldo et al. 2014a). A metformin-mediated improvement of sperm motility and viability was obtained after this procedure was applied to chicken spermatozoa (Nguyen et al. 2014). The main mechanism of action of metformin is not completely elucidated. However, it is known that one of its actions is to block the respiratory chain complex I and inhibit ATP synthesis in mitochondria (Rena et al. 2013). This action increases the AMP/ATP ratio, which induces and activates indirectly the energy sensor called AMP-activated protein kinase (AMPK).

Therefore, the aim of this study was to understand if metformin, which mimics food restriction and modulates cellular metabolism, affects the Sertoli and germ cell populations. Two complementary approaches were used, including i) the culture of chicken Sertoli cells and seminiferous tubules exposed to metformin and ii) in vivo administration of metformin to prepubertal chickens for 3 weeks to assess the consequences on testicular development and spermatogenesis.

\section{Materials and methods}

\section{Animals}

Male chickens (Ross) were purchased from the 'Institut de Sélection Animale', Saint Brieuc, France. Chickens were housed with access to feed and water ad libitum and were maintained in a $16 \mathrm{~h}$ light:8 $\mathrm{h}$ darkness photoperiod. All animal procedures were carried out in accordance with the European legislation for animal experimentation (directive 86/609/EEC) and with French legislation on animal research. The procedures were approved by the Ethics Committee of Val de Loire (CEEA VdL, Comité d'Ethique pour l'Expérimentation
Animale du Val de Loire, no. 01607.02). For in vivo exposure, chickens were treated with $0.5 \mathrm{mg} / \mathrm{mL}$ metformin in the drinking water (Sigma) starting at 6 weeks of age for 3 weeks in order to provide an average dose of $150 \mathrm{mg} / \mathrm{kg}$ per day, with the concentration of metformin adjusted in the drinking water each day (Chen et al. 2011). We carried out two experiments with four birds per condition.

\section{Physiological and blood parameters}

Feed, water intake and body weight were monitored every 2 days for each animal/condition. Blood was collected after overnight-fasting and then after a regular feeding. Glucose, phospholipid, triglycerides and cholesterol concentrations were measured in blood by using spectrophotometric assays (Sigma and Biolabo, Maizy, France). After the animal were killed, abdominal fat was retrieved and weighted.

\section{Culture of chicken Sertoli cells}

For each culture, Sertoli cells were purified from testis of two 6-week-old chickens previously killed by electronarcosis as described previously (Guibert et al. 2011, 2013). Sertoli cells were cultured in HEPES-buffered F12/ DMEM (Sigma) supplemented with 100 units $/ \mathrm{mL}$ penicillin and $100 \mu \mathrm{g} / \mathrm{mL}$ streptomycin (Sigma) and 5\% FCS for $12 \mathrm{~h}$ at $37^{\circ} \mathrm{C}$ in a humidified atmosphere of $5 \% \mathrm{CO}_{2}$. The medium was changed to $1 \%$ FCS every $48 \mathrm{~h}$. Sertoli cells were seeded at a density of $5 \times 10^{5}$ cells/well and stimulated or not for $48 \mathrm{~h}$ with metformin $(5 \mathrm{mM})$ followed by a short stimulation $(15 \mathrm{~min})$ with $10 \mathrm{ng} /$ $\mathrm{mL}$ ovine follicle-stimulating hormone (oFSH; Sigma) for immunoblotting or only with metformin to measure metabolite content (lactate, ATP). The metformin concentration was selected after kinetic and dose-response experiments performed on the ability to phosphorylate the AMPK, a molecular target of metformin, in chicken Sertoli cells. The 5-bromodeoxyuridine (BrdU) incorporation analysis was carried out on Sertoli cells seeded in chamber slides $\left(2.5 \times 10^{4}\right.$ cells/chamber). After stimulation, the media and cells were collected and stored at $-80^{\circ} \mathrm{C}$ until analysis. At least three to eight different cultures were carried out as described in the figure legends.

\section{Culture of chicken seminiferous tubules}

Seminiferous tubules (containing germ and Sertoli cells) from 6-week-old chickens contain mainly spermatogonia and type I spermatocytes. Seminiferous tubules were prepared as described previously (Guibert et al. 2013) and seeded in static 24-well cell culture polyethylene terephthalate inserts (pore $0.4 \mu \mathrm{m}, \mathrm{WWR}$, Fontenay sous Bois, France) as described previously (Djakiew \& Dym 1988, Staub et al. 2000, Legendre et al. 2010). This was carried out in order to preserve germ cells on polarised Sertoli cells in a dynamic culture using the Quasi-Vivo system (Kirkstall Ltd, Rotherham, UK). The Quasi-Vivo System places inserts in silicone culture QV500 chambers (same dimension as those of 24-well plates) that permit culture medium to flow $(250 \mu \mathrm{L} / \mathrm{min})$ for $96 \mathrm{~h}$ (Supplemental Data 1, see section on supplementary data given at the end of this article; Pirke et al. 1982). The density of 
seminiferous tubules seeded per insert was estimated at 120 000 cells/insert. The culture medium consisted of F12/DMEM supplemented with antibiotics, $500 \mu \mathrm{M}$ pyruvate, $10 \mu \mathrm{g} / \mathrm{mL}$ transferrin, $10^{7} \mathrm{M}$ testosterone, $17.6 \mu \mathrm{g} / \mathrm{mL}$ vitamin $\mathrm{C}, 10 \mu \mathrm{g} / \mathrm{mL}$ vitamin E, $86 \mathrm{ng} / \mathrm{mL}$ vitamin $\mathrm{A}, 5 \mathrm{ng} / \mathrm{mL}$ oFSH and $1.10^{9} \mathrm{M}$ recombinant human insulin-like growth factor 1 (Sigma), and $1 \%$ FCS (GE Healthcare, Velizy-Villacoublay, France). The concentration of compounds in the medium was similar or less than that measured in chicken blood, except for the testosterone secreted by Leydig cells which present in the testis at higher levels than in the blood flow. In static culture, only the basal medium was changed every $48 \mathrm{~h}$. After $96 \mathrm{~h}$ of metformin (5 mM) incubation, cells were trypsinised, fixed for $10 \mathrm{~min}$ in $4 \%$ paraformaldehyde (PFA)/PBS, and stored at $+4^{\circ} \mathrm{C}$ until immunostaining for flow cytometric analysis. Six different cultures were repeated.

\section{Cell proliferation of chicken Sertoli cells}

For BrdU incorporation, the cells were seeded at a density of $2.5 \times 10^{4}$ cells/well in DMEM/F12 supplemented with $5 \%$ FCS for $12 \mathrm{~h}$, then the medium was changed which contained DMEM/F12 with 1\% FCS, and the cells were cultured in the presence or absence of insulin $(100 \mathrm{ng} / \mathrm{mL}$, Sigma) or metformin (5 mM, Sigma) for $48 \mathrm{~h}$. Twenty-four hours after stimulation, 10 $\mu \mathrm{M}$ BrdU (Sigma) was added to the culture medium for $24 \mathrm{~h}$. Finally, cells were fixed in $4 \%$ PFA/PBS. BrdU positive cells were identified by indirect immunofluorescence as described in Migliorini et al. (2002) and counted with a minimum of 100 cells in duplicate for each culture condition and per culture. Analysis was carried out on three different cultures.

\section{Immunohistochemistry}

Chicken testes fixed in formalin were embedded in paraffin after successive dehydration steps. About $5 \mu \mathrm{m}$ thick sections were deparaffined, rehydrated, and microwaved for $5 \mathrm{~min}$ in an antigen unmasking solution (Vector Laboratories, Inc., AbCys, Paris, France). After washing (5 min twice in PBS), the sections were immersed for $10 \mathrm{~min}$ in peroxidase blocking reagent to quench endogenous peroxidase activity (DAKO Cytomation, Ely, UK). After washing, non-specific background was eliminated by blocking with $5 \%$ lamb serum in PBS for $20 \mathrm{~min}$, followed by an overnight incubation at $4{ }^{\circ} \mathrm{C}$ with PBSBSA $1 \%$ and primary antibody at 1:100 dilution. Antibodies raised against pan-AMPK $\alpha$ (PRKAA1) (both isoforms, Upstate Biotechnology, Inc., Lake Placid, NY, USA), pan-AMPK $\beta$ (PRKAB1) (both isoforms), AMPK $\gamma 1$ (PRKAG1), and AMPK 33 (PRKAG3) (Cell Signalling). Rabbit IGG was used as a negative control. The washed sections were incubated for $1 \mathrm{~h}$ with a ready-to-use-labelled polymer- HRP anti-rabbit solution (DAKO Cytomation Envision plus HRP System). Then, sections were washed and incubated in 3,3'-diaminobenzidine solution (Sigma). The slides were counterstained with Meyer's haematoxylin and mounted in mounting medium (Sigma).

\section{Immunofluorescence}

Deparaffinised and rehydrated $5 \mu \mathrm{m}$ sections were washed in PBS, then incubated in $0.1 \mathrm{M}$ glycine/PBS (15 min) and permeabilised with $0.15 \%$ Triton X-100 (w/v) in PBS containing 1\% BSA (20 min). Non-specific binding sites were blocked by incubating in $2 \%$ BSA/PBS (20 min).

The germ cells were stained by antibodies produced by immunisation against the purified $\mathrm{N}$-terminal partial of the chicken Vasa homologue $(\mathrm{cVH})$ protein raised in rabbit (Guibert et al. 2013). cVH is a germ cell marker detected in cell stages from spermatogonia to round permatids (Tsunekawa et al. 2000, Lavial et al. 2009). The sections or cells were incubated $60 \mathrm{~min}$ with anti-cVH antibody (diluted at 1:100) or chAMH rabbit serum. The rabbit serum was produced by immunisation with purified N-terminal His-tagged partial chicken AMH protein (from amino acid 66 to the C-terminus) and was a kind gift of Drs D Carré-Eusèbe and E Oréal (INSERM U782, Clamart, France). Then the section were washed and incubated with a goat anti-rabbit Alexa-488 antibody (1:500, 30 min, Invitrogen) at room temperature, protected from light. After a next wash, the sections were mounted in Vectashield Mounting Medium (Vector Laboratories, Inc., AbCys).

\section{Morphometric measurements of seminiferous tubules}

The diameters of seminiferous tubules were measured with round or nearly round tubules from each testicular section stained with Meyer's haematoxylin (Sigma). At least 40 measurements of diameter of transverse sections of seminiferous tubules for each testis were measured using an ocular measuring device. Analysis was carried out on four different chickens per treatment.

\section{Apoptosis analysis}

Activity of the cleaved form of caspase 3 (CASP3), a mediator of programmed cell death, was measured by caspase 3/7 Glow Assays according to the manufacturer's instructions (Promega). Doxorubicin is a chemotherapeutic agent used in the treatment of cancer. As a positive control, cells were exposed to doxorubicin $(0.2 \mu \mathrm{g} / \mathrm{mL})$ for $24 \mathrm{~h}$ (Sigma) as described in Froment et al. (2008). Analysis was carried out on three different cultures in triplicate for each condition.

\section{Metabolites and hormone assays}

Lactate and glucose concentrations were determined according to commercial spectrophotometric assays (Sigma), phospholipid, triglyceride, and cholesterol concentrations were measured in blood using a colorimetric assay kit (Biolabo). CAMP and ATP concentrations were measured by using the cAMP-Glo Assay and the Cell-Titer-Glo Assay (Promega). The testosterone concentrations were determined by RIA in blood after solvent extraction as described previously (Hochereau-de Reviers et al. 1990). The sensitivity of the assay was $15 \mathrm{pg} /$ tube, and the intra-assay coefficient of variation $(\mathrm{CV})$ was $5.3 \%$. Inhibin concentrations were measured using an enzyme immunoassay (EIA) with inhibin, the $\alpha$-subunit (1-32) (Human) ElA Kit (Phoenix Pharmaceuticals, Inc., Belmont, CA, USA). The inhibin EIA Kit has previously been tested in chicken (Blomqvist et al. 2006). The intra-assay CV was below $10 \%$, and the average detection limit of the assay was $0.09 \mathrm{ng} / \mathrm{mL}$. All standards and samples were assayed 
in triplicate. The results obtained from testis lysates for each assay were normalised with the protein concentration in each sample. At least three different cultures were analysed as detailed in figure legends.

\section{PCNA, DAZL and PTM1 assays}

The measurement of the following cell markers in the testis lysates was carried out by ELISA Kit to analyse cell proliferation (chicken proliferating cell nuclear antigen, PCNA, a marker of cell proliferation, Cusabio, Eurobio, Courtaboeuf, France; $n=5$ cultures), the immature germ cell content (chicken deleted in azoospermia-like, DAZL, a marker of spermatogonia; Cusabio, Eurobio; $n=6$ different chickens/condition), and the mature germ cell population (chicken protamine 1, PTM1, a marker of spermatid, Bluegene, Hoelzel-Biotech, Köln, Germany; $n=5$ different chickens/condition).

\section{Immunoblotting}

Testis and isolated Sertoli cells were prepared by three repeated freeze-thaw cycles in a lysis buffer containing $(10 \mathrm{mM}$ Tris $(\mathrm{pH}$ 7.4), $150 \mathrm{mM} \mathrm{NaCl}, 1 \mathrm{mM}$ EDTA, $1 \mathrm{mM}$ EGTA and 0.5\% lgepal) and protease and phosphatase inhibitors (Sigma) as described in Froment (2004). Proteins were submitted to electrophoresis on SDS-PAGE under reducing conditions. After transfer, the membranes were incubated overnight at $4{ }^{\circ} \mathrm{C}$ with antibodies against phospho-(Thr172) AMPK $\alpha$ (New England Biolabs, Inc., Beverly, MA, USA), AMPK 1 (Upstate Biotechnology, Inc.), PCNA, phosphorylated (Ser473) protein kinase B (AKT), AKT, phosphorylated (Thr202/Tyr204) ERK1/2, cyclin D2 (Cell Signalling), ERK, P21 and P27 (Santa Cruz Biotechnology), and vinculin (VCL) (Sigma). All antibodies were used at 1:1000 dilution. As secondary antibodies, HRP-linked sheep anti-mouse IGG antibody or donkey anti-rabbit IgG antibody (1:10 000, Amersham Biosciences) was used. The signal was detected by ECL (Amersham Pharmacia) and quantified using Image Analysis Software (ImageJ, v 1.48, NIH). The results are expressed as signal intensity in arbitrary units, after normalisation by an internal standard (total protein for phosphorylated proteins or vinculin) and correspond to the mean of three separate experiments.

\section{Flow cytometric analysis}

Cultured seminiferous tubules were trypsinised, fixed in $4 \%$ PFA/PBS, washed with PBS and permeabilised (20 min) on ice with $0.15 \%$ Triton $X-100(\mathrm{w} / \mathrm{v})$ in PBS containing $1 \%$ BSA as described in Guibert et al. (2011). Analysis was carried out on six different cultures.

Then, cells were incubated with an anti-cVH antibody (diluted at $1: 100$ ) in blocking buffer (PBS/1\% BSA $10 \%$ FCS) for $2 \mathrm{~h}$ at $4^{\circ} \mathrm{C}$. The incorporation of $\mathrm{BrdU}$ in mitotic or meiotic DNA was quantified by the modified protocol described earlier using the anti-BrdU antibody. For negative control, cells were incubated with mouse or rabbit IGG. After washes in 1\% BSA PBS, cells were incubated with a goat anti-rabbit Alexa 633 antibody or a goat anti-mouse Alexa-488 antibody (1:500, 2 h at $4{ }^{\circ} \mathrm{C}$; Invitrogen) in blocking buffer. After the last wash, the labelled cells were filtered in a $70 \mu \mathrm{m}$ pore size cell strainer and analysed with a MoFlo High-Speed Cell Sorter (Beckman Coulter) equipped with a solid-state laser operating at $488 \mathrm{~nm}$ and $100 \mathrm{~mW}$. Forward scatter and side scatter were recorded to define the morphological characteristics and provide gating parameters for selection of the testicular cells population. A minimum of $4 \times 10^{4}$ cells was counted for each analysis. Files were further analysed using Summit 4.3 Software (Beckman Coulter).

\section{Statistical analyses}

Data were presented as the mean \pm S.E.M. One-way ANOVA followed by the Newman-Keuls post hoc test, or two-way ANOVA followed by the Bonferroni's post hoc test, was used to compare different conditions and cultures. Unpaired t-test was used to compare treated animals with control animals. Statistical analysis was performed by using GraphPad Prism 5. Values were determined to be significant when $P \leq 0.05$, $* P<0.05 ;{ }^{* *} P<0.01$ and ${ }^{* * *} P<0.001$ or $\mathrm{a}, \mathrm{b}$ and $\mathrm{c}$ when $P \leq 0.05$ for different conditions.

\section{Results}

\section{Proliferation of chicken Sertoli cells in vitro}

There were no clear differences in cellular morphology of chicken Sertoli cells cultured in the presence of metformin (Fig. 1A). However, an investigation of the effects of metformin on the proliferation of Sertoli cells in vitro revealed a significant 20\% decrease in BrdU-positive Sertoli cells in comparison to that of the control (Fig. 1B). As expected, insulin used as a positive control increased the proliferative capabilities of Sertoli cells (Fig. 1B). These results were confirmed by the expression of PCNA, which was significantly reduced after metformin treatment, and an increase in the P21 levels (Fig. 1D). However, a slight but not significant decrease in cyclin D2 (CCND2) levels was observed (Supplemental Data 2). In addition, metformin exposure for $48 \mathrm{~h}$ did not significantly modify the activities of caspase $3 / 7$, a marker associated with apoptosis (Fig. 1C), and these results were consistent with those obtained by trypan blue exclusion staining (data not shown).

\section{Bioenergetic activity of chicken Sertoli cells}

We next investigated whether metformin modified energy production in Sertoli cells. The ATP production was reduced to $70 \%$ after metformin treatment (Fig. 2A) and the amount of lactate secreted into the culture media (Fig. 2C) was increased by twofold when cells were treated with metformin. Regarding CAMP, an important intracellular signalling factor of Sertoli cells (Fig. 2B), and inhibin, an important reproductive hormone (Supplemental Data 3A), no significant differences were observed in their productions. Two additional pathways playing an important role in the secretion or interaction functions in Sertoli cells were studied, including the phosphoinositide-3-kinase (PI3K)/AKT and MAPK/ERK 
A
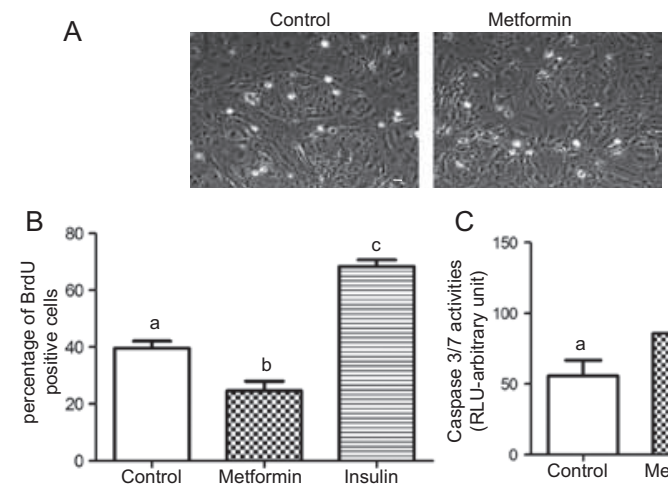

C
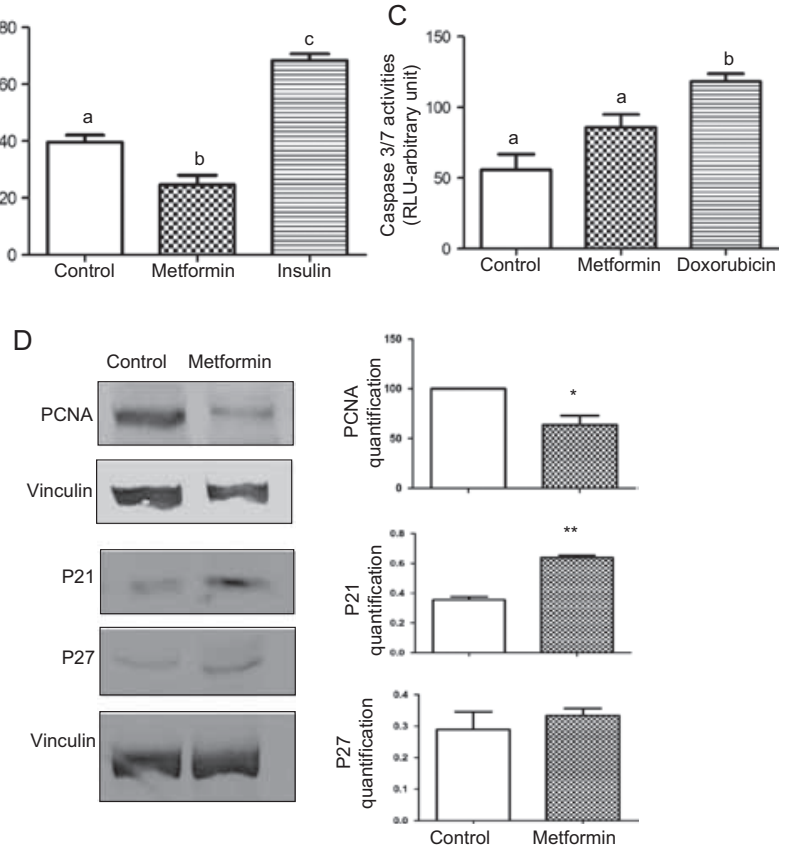

Figure 1 Metformin reduces the proliferative ability of Sertoli cells. (A) Brightfield image of purified Sertoli cells after $48 \mathrm{~h}$ of stimulation with or without metformin $(5 \mathrm{mM})$, scale bar $=20 \mu \mathrm{m}$. (B) Percentage of proliferating Sertoli cells measured as BrdU-positive cells with or without metformin exposure ( $5 \mathrm{mM}$ for $48 \mathrm{~h}$ ). Insulin was used as the positive control $(100 \mathrm{ng} / \mathrm{mL}$; control $n=4$, metformin $n=3$, insulin $n=3$, each condition per culture was carried out in duplicate). (C) Apoptosis was measured by cleaved caspase 3 activity. Caspase 3/7 activities were evaluated after $48 \mathrm{~h}$ of metformin $(5 \mathrm{mM})$.

Doxorubicin was used as a positive control $(0.2 \mu \mathrm{g} / \mathrm{mL}$ for $24 \mathrm{~h} ; n=3$ experiment carried out in triplicate). (D) PCNA, P21 and P27 expression was measured by western blotting analysis. Sertoli cells were stimulated for $48 \mathrm{~h}$ with or without metformin $(5 \mathrm{mM})$. Expression levels were normalised by vinculin $(n=3-5)$. Different letters indicate significant differences $(P<0.05) .{ }^{*} P<0.05$ and ${ }^{* *} P<0.01$.

pathway (Crepieux et al. 2001, Khan et al. 2002). Under the conditions evaluated in this study, metformin was associated with a trending but not significant increase in AKT phosphorylation (Fig. 3A). In addition, ERK phosphorylation was increased after oFSH stimulation, but metformin exhibited no effect on ERK compared with the control (Fig. 3B). The ERK pathway is regulated by $\mathrm{FSH}$ and could modulate Sertoli cells function, but it is unknown whether AKT and ERK are involved in the action of metformin in controlling testicular function.

\section{Consequences of metformin on germ cell populations in vitro}

The consequences of metformin on germ cell maturation were studied using a culture of seminiferous tubules in a static culture (inserts) and in a dynamic culture using the Quasi-Vivo System in which the culture medium continually circulated and mimicked blood flow (Supplemental Data 1). The number of germ cells was quantified by flow cytometry. Germ cells were detected after immunolabelling against the cVH (Fig. 4A, arrow). Flow cytometry showed that the population of $\mathrm{cVH}$ immunoreactive cells had incorporated BrdU (Fig. 4B, circle). In the two systems, the number of germ cells was reduced in the presence of metformin treatment. A 90\% reduction in $\mathrm{CVH}$ cells incorporating BrdU was observed after exposure to metformin in static culture (Fig. 4C).

\section{AMPK: an energy sensor activated by metformin in the chicken testis}

We localised by immunohistochemistry the presence of several AMPK subunits in chicken testes. The AMPK $\alpha 1 / 2$ subunit is expressed in seminiferous tubules and to a lesser extent in Leydig cells (Fig. 5A). The AMPK $\beta 1 / 2$ and $A M P K \gamma 1$ subunit are mainly expressed within seminiferous tubules (Fig. 5A). AMPK $\gamma 3$ is located only in Leydig cells (Fig. 5A). Thus, we have tested if metformin is able to activate AMPK in Sertoli cells which composed the seminiferous tubules. In purified Sertoli cells, at least $500 \mu \mathrm{M}$ metformin concentration was required for optimal phosphorylation of catalytic subunit of AMPK (Supplemental Data 4A) and the time required for stimulation was 60 min (Supplemental Data 4B).

\section{Effect of metformin treatment in chicken}

To measure the effect of metformin administration on testis development under in vivo conditions, chronic exposure to metformin was carried out by adding $150 \mathrm{mg} /$ $\mathrm{kg}$ metformin to the drinking water. The treatment was

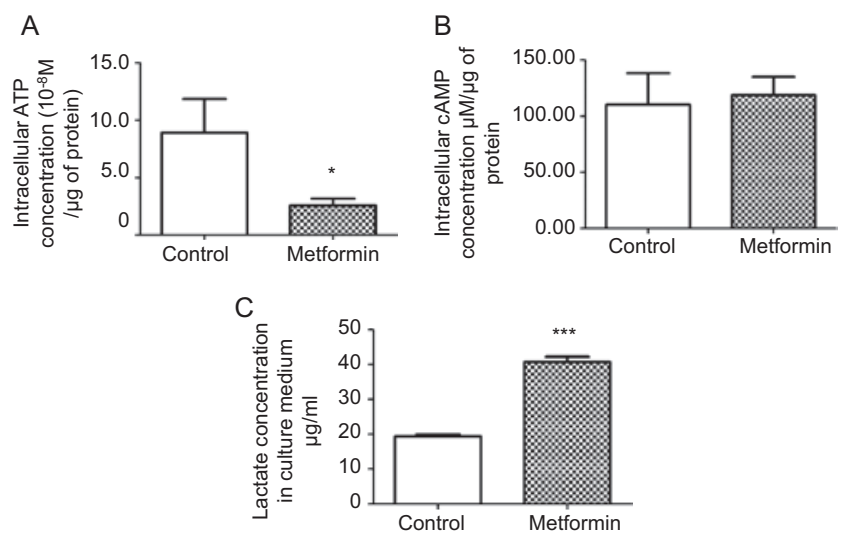

Figure 2 Activities of Sertoli cells in culture. (A) Intracellular ATP and (B) intracellular cAMP concentrations in Sertoli cells were measured after $48 \mathrm{~h}$ of metformin exposure $(5 \mathrm{mM}), n=7$ experiments for ATP and $n=6$ experiments for cAMP. (C) The lactate concentration secreted by Sertoli cells was measured in the culture medium after $48 \mathrm{~h}$ of metformin treatment $(5 \mathrm{mM}), n=6$ experiments. ${ }^{*} P<0.05$ and $* * * P<0.001$. 
A

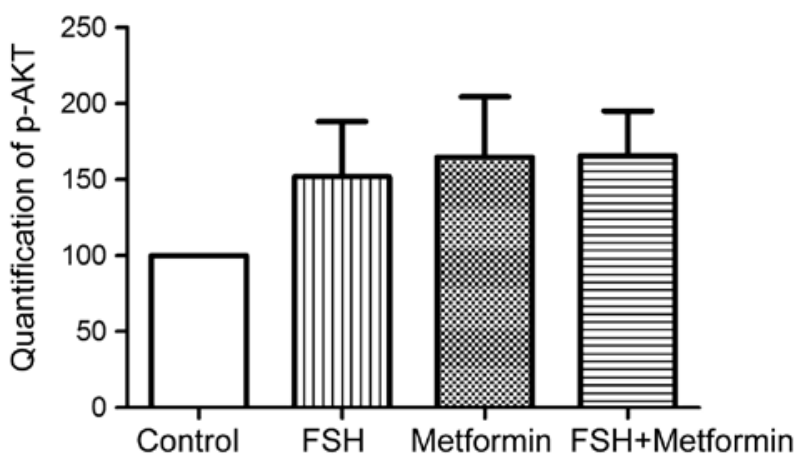

p-AKT

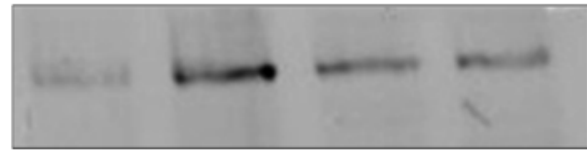

AKT total

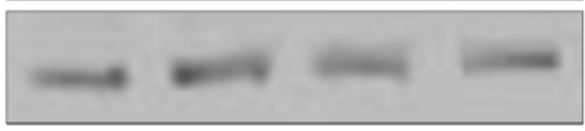

B
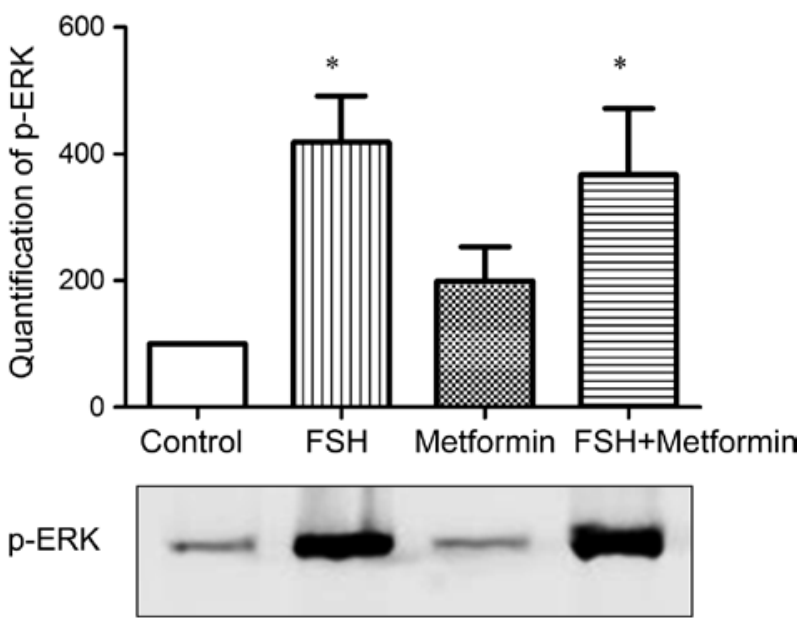

ERK total

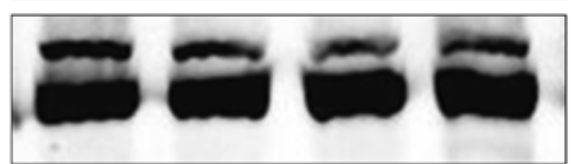

Figure 3 AKT and ERK signalling pathways in Sertoli cells. (A) Western blotting analysis of phosphorylated AKT and (B) phosphorylated ERK in Sertoli cells stimulated or not by metformin $(5 \mathrm{mM}$ for $48 \mathrm{~h}$ ) followed by a short stimulation (15 min) with oFSH $(10 \mathrm{ng} / \mathrm{mL})$. AKT and ERK phosphorylation was normalised by total protein, $n=8$ experiments. ${ }^{*} P<0.05$.

carried out for 3 weeks beginning at 6 weeks of age (prepubertal stage). After exposure, neither the food intake nor water consumption was affected (Table 1). The weight gain of chickens was not modified, and the same weight was observed for abdominal fat/total body weight (Table 1). Analyses of blood parameters in the two group (Table 2) did not show a difference in the glucose, phospholipid, cholesterol and triglyceride parameters when animals were fasted or were fed.

\section{Effect of metformin on markers of testis development}

The weight of testes of animals treated with metformin significantly decreased by $40 \%$ in comparison to that of control testes (Fig. 6A). This result was associated with a reduction in the diameter of the seminiferous tubules in treated chickens (Fig. 6B). It should be noted that the lumen was more developed in control testes, and also the presence of few spermatids (arrows) in the adluminal area in contrast to testes treated with metformin (Fig. 6C). Furthermore, strong AMH staining was localised around the lumen in metformin-treated testes (Fig. 6D). The decreased level of PCNA observed in vitro was not recovered in the testis lysates (Fig. 6E). No apoptosis was observed after metformin exposure (Fig. 6F). In addition, testosterone levels were significantly lower in treated chickens compared with controls (Fig. 7A), but the serum concentration of inhibin did not differ significantly (Supplemental Data 3B). The intratesticular content of ATP (Fig. 7B) was reduced following metformin treatment,

A

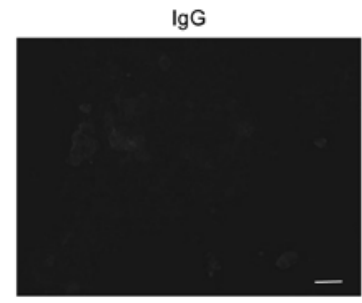

B
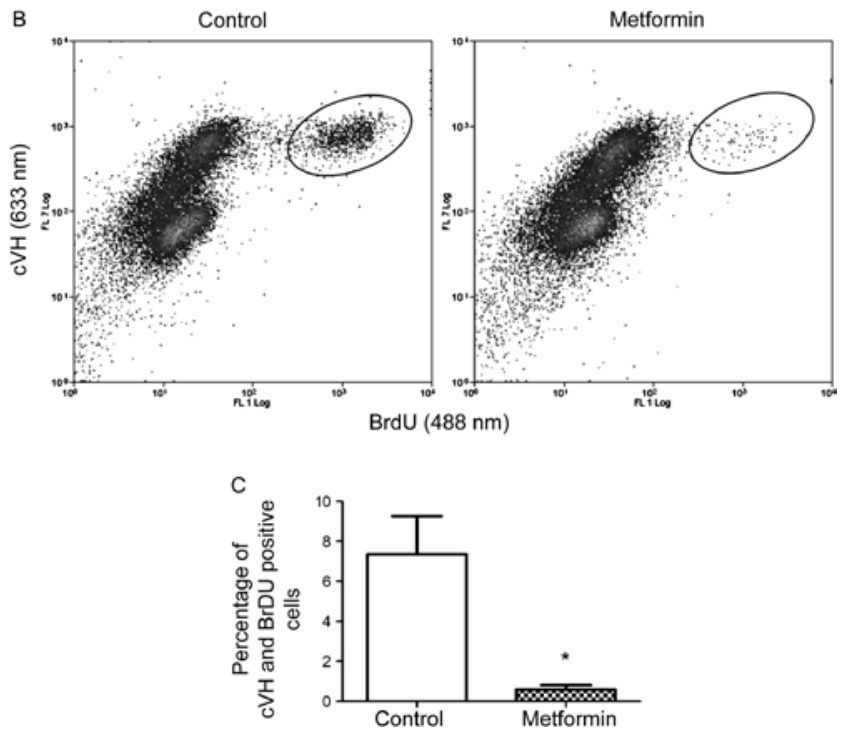

Figure 4 Consequences of metformin exposure on seminiferous tubule in culture. (A) Immunocytochemistry of cVH in cultures of seminiferous tubules. Germ cells are indicated by the white arrowheads. Scale bar $=10 \mu \mathrm{m}$. (B) Proliferative germ cells were quantified after a 96-h culture stimulated or not by metformin (5 mM) for $48 \mathrm{~h}$. Germ cells are cVH-immunoreactive cells and proliferative cells are BrdU-positive (black circle) in the representative windows of cells analysed by flow cytometry. (C) Quantification of germ cells in static seminiferous tubule culture displaying incorporated BrdU (cVH- and BrdU-positive cells). ${ }^{*} P<0.05$ ( $n=6$ experiments (pool of four wells in each condition)). 

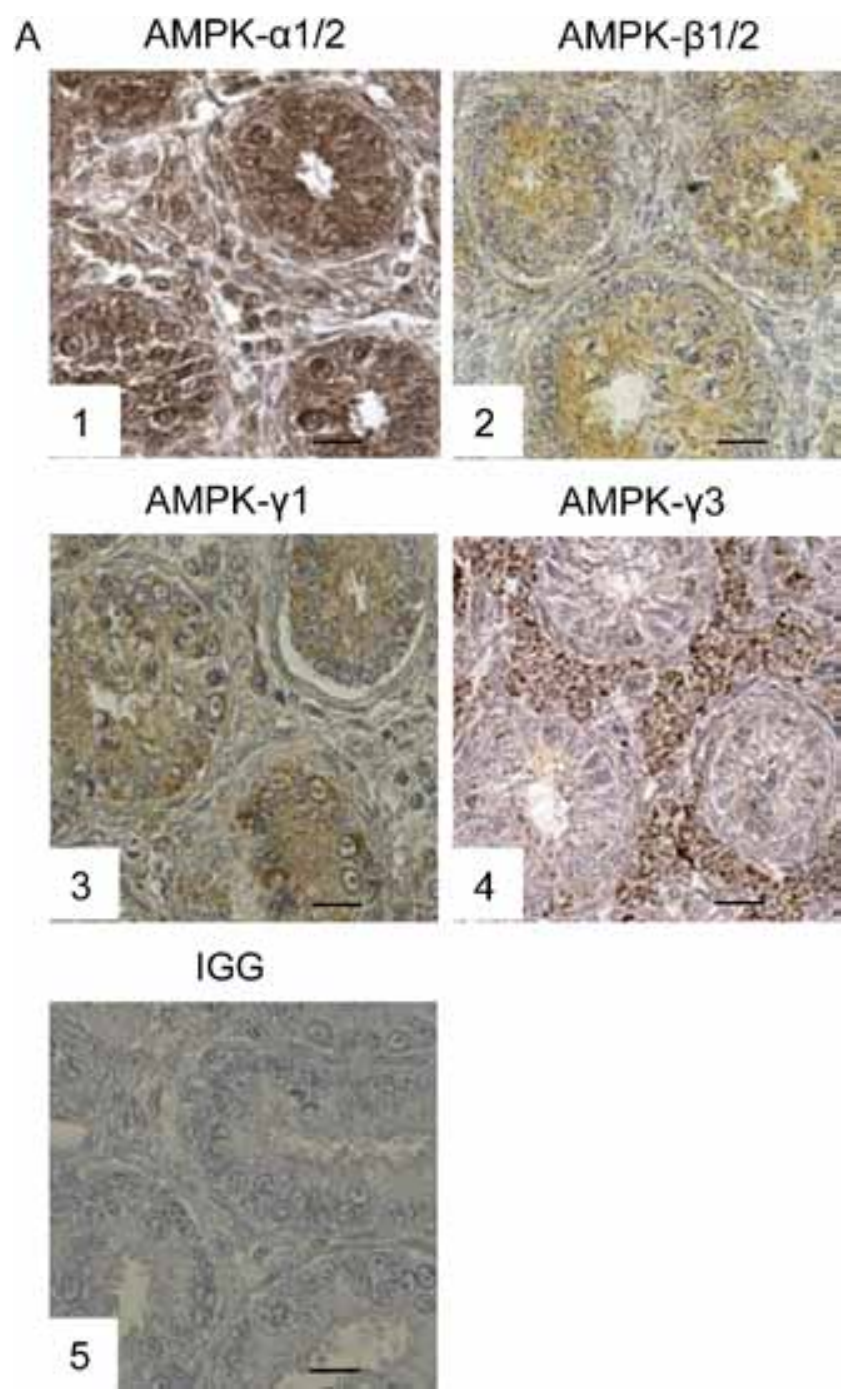

Figure 5 AMPK is activated by metformin in chicken testis.

(A) Representative microscopic fields of testicular sections of 6-week-old chickens immunostained for (1) AMPK $\alpha 1 / 2$,

(2) AMPK $\beta 1 / 2$, (3) AMPK $\gamma 1$, (4) AMPK $\gamma 3$ and (5) IGG (used as a negative control). Scale bar $=20 \mu \mathrm{m}$.

which is consistent with the in vitro data. No difference was observed in CAMP content (Fig. 7C) and the lactate content in vivo after metformin treatment (Fig. 7D).

Finally, we measured the consequences of metformin administration on the germ cell population by immunostaining with the $\mathrm{CVH}$ marker. During male germ cell development, $\mathrm{cVH}$ protein is expressed from the
Table 1 Metformin consequences on production parameters.

\begin{tabular}{|c|c|c|c|}
\hline Parameter & Control & Metformin & $n$ \\
\hline Feeding weight (g/24 h) & $103 \pm 3$ & $116 \pm 6^{\mathrm{NS}}$ & 4 \\
\hline $\begin{array}{l}\text { Drinking volume } \\
(\mathrm{mL} / 24 \mathrm{~h})\end{array}$ & $180 \pm 15$ & $262 \pm 22^{\mathrm{NS}}$ & 4 \\
\hline $\begin{array}{l}\text { Weight gain after } 3 \\
\text { weeks of treatment (\%) }\end{array}$ & $171.1 \pm 5.8$ & $178.85 .8^{\mathrm{NS}}$ & 4 \\
\hline $\begin{array}{l}\text { Ratio of abdominal fat } \\
\text { weight/body weight }\end{array}$ & $6.6 \pm 3.1$ & $11.2 \pm 2.3^{\mathrm{NS}}$ & 4 \\
\hline
\end{tabular}

Statistical analysis between metformin and control group was determined by a Student's $t$-test.

spermatogonia stage to the spermatid stage. In control testes, somec $\mathrm{VH}$-negativegerm cells were localised around the lumen of the seminiferous tubules (Fig. 8A1 and A2), suggesting the presence of the most mature germ cells, but which are absent in metformin-treated testes (Fig. 8A3 and A4). Quantification of the specific primordial germ cell marker DAZL, reflecting the abundance of spermatogonia (Rengaraj et al. 2010), was not altered between the two groups (Fig. 8B). However, the content of the spermatidspecific marker, protamine, was significantly lower in metformin-treated testes compared with control testes $((7.9 \pm 0.5 \mathrm{ng}$ protamine/ $\mu \mathrm{g}$ total protein for control vs $5.8 \pm 0.4 \mathrm{ng}$ protamin/ $\mu \mathrm{g}$ total protein on metformin testis, Fig. $8 \mathrm{~B}$ ) as observed in Fig. 8A), suggesting a delay in the maturation of germ cells.

\section{Discussion}

In this study, we showed that in vitro metformin exposure was associated with reduced cellular proliferation and variations in the secretory ability of Sertoli cells. Moreover, we demonstrated a negative effect of metformin exposure on the germ cell population. In vivo, metformin exposure induced a decrease in testis weight and in spermatid production, suggesting that 3 weeks of metformin administration in drinking water is sufficient to delay spermatogenesis. The phenotype induced by metformin exposure could in part involve the energy sensor AMPK.

The first effect measured in vitro after metformin exposure was a reduction in cellular proliferation. We observed a reduction in cellular proliferation in vitro after metformin treatment. Accordingly, in vivo metformin treatment of an immature chicken induced a decrease in testis weight. The prepubertal period in chickens (7-10 weeks old) is a proliferative period for Sertoli cells and crucial for growth because the number of total Sertoli cells per testis increases from 1 to 5 million at 1 day of

Table 2 Metformin consequences on metabolic markers.

\begin{tabular}{|c|c|c|c|c|c|}
\hline \multirow[b]{2}{*}{ Parameter } & \multicolumn{2}{|c|}{ Control } & \multicolumn{2}{|c|}{ Metformin } & \multirow[b]{2}{*}{$n$} \\
\hline & Starved & Feed & Starved & Feed & \\
\hline \multicolumn{6}{|l|}{ Context } \\
\hline Glucose levels (mg/dL) & $242.0 \pm 27.1$ & $304.5 \pm 17.1$ & $298.0 \pm 15.6^{\mathrm{NS}}$ & $340 \pm 11.8^{\mathrm{NS}}$ & 4 \\
\hline Phospholipids levels (g/L) & $1.9 \pm 0.2$ & $1.7 \pm 2.3$ & $1.8 \pm 0.1^{\mathrm{NS}}$ & $1.5 \pm 0.1^{\mathrm{NS}}$ & 8 \\
\hline Triglycerids levels (g/L) & $1.3 \pm 0.4$ & $1.4 \pm 0.5$ & $1.9 \pm 0.6^{\mathrm{NS}}$ & $2.0 \pm 0.7^{\mathrm{NS}}$ & 8 \\
\hline Cholesterol levels (g/L) & $1.2 \pm 0.1$ & $1.8 \pm 0.6$ & $1.3 \pm 0.1^{\mathrm{NS}}$ & $1.3 \pm 0.1^{\mathrm{NS}}$ & 8 \\
\hline
\end{tabular}

Statistical analysis between metformin and control group was determined by a Student's $t$-test. 

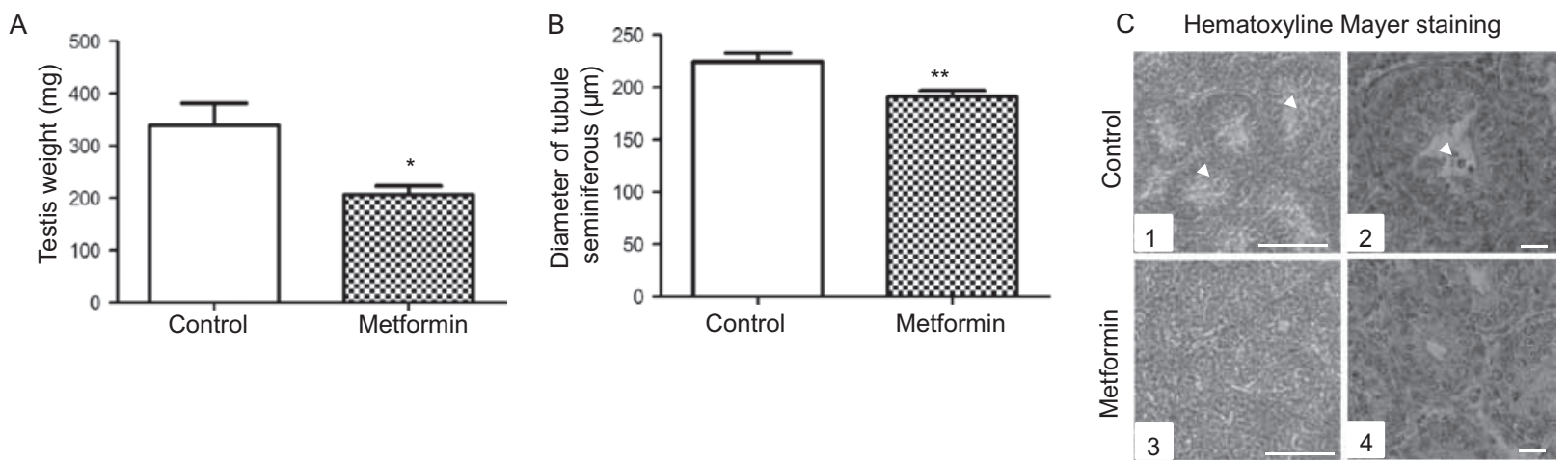

$\mathrm{D}$
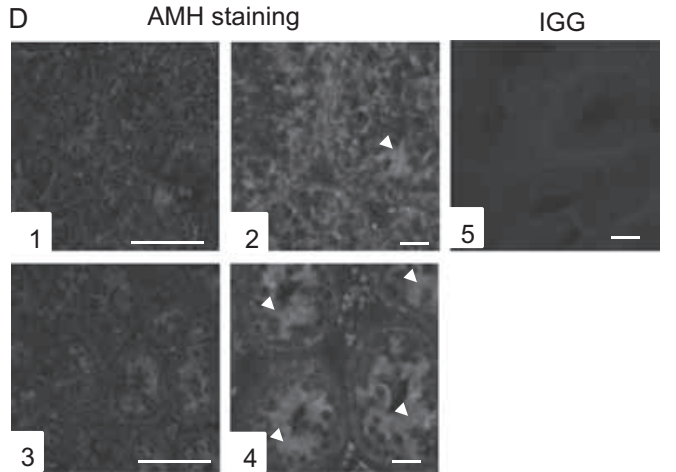

E
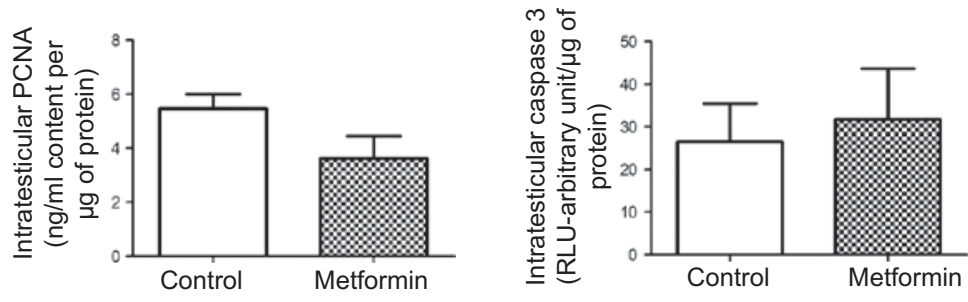

Figure 6 Consequences of metformin administration on testis growth. (A) Testis weight after 3 weeks of metformin administration ( $n=3$ animals/ condition). (B) Diameter of round section of seminiferous tubules from chickens treated with metformin or control chickens ( $n=4$ animals/ condition). (C) Representative Mayer's haematoxylin staining of testicular sections from chickens stimulated with metformin or not for 3 weeks. White arrows indicate spermatids. Scale bar $(1$ and 3$)=100 \mu \mathrm{m}$ and scale bar $(2$ and 4$)=20 \mu \mathrm{m}$. (D) Immunohistochemistry of AMH on untreated testis ( 1 and 2 ) or after metformin exposure (3 and 4). IGG was used as a control (5). Scale bar (1 and 3)=100 $\mu \mathrm{m}$ and scale bar (2, 4 and 5) $=20 \mu \mathrm{m}$. White arrows indicate cytoplasmic AMH staining. (E) Cell proliferation in testis was measured after 3 weeks of metformin treatment by quantification of the intratesticular PCNA content ( $n=5$ animals/condition) and (F) apoptosis was analysed through the activity of the cleaved caspase 3 ( $n=6$ animals/condition). ${ }^{*} P<0.05$ and $* * P<0.01$.

age to more than 100 million Sertoli cells/testis at 8-10 weeks of age (de Reviers et al. 1971). In addition, the number of Sertoli cells is critical in determining testicular weight and sperm production (de Reviers 1980), because Sertoli cells support a relatively fixed number of germ cells in each species (Holsberger et al. 2005). Although we observed a reduction in the proliferative activity of Sertoli cells and germ cell population in vitro, the population of spermatogonia in vivo was not altered. This suggests that an inhibition in mitosis and/or meiosis would have occurred. This hypothesis is in agreement with previous studies in which deletion of two genes encoding the inhibitors of the cell cycle (p27Kip1 and p21Cip1) in mouse Sertoli cells increased the Sertoli cell population, the testis weight and daily sperm production (Holsberger et al. 2005). In addition, previous studies have described the inhibition of cell proliferation after metformin treatment in cells derived from breast cancer (Alimova et al. 2009) and colon cancer (Buzzai et al. 2007). Moreover, the protein levels of cyclin D2, a factor present in Sertoli cells that is critical for the G1/S progression factor, are not clearly affected (Tan et al. 2005). However, in our model, we have shown that the inhibition of the cell cycle by metformin could be realised by higher P21 levels.
Because the main role of Sertoli cells is to support and nurse the germ cells, we have evaluated the differentiated functions of Sertoli cells by measuring the production of lactate and inhibin, which are two major products of Sertoli cells (Jutte et al. 1981). In vitro we observed that metformin induced a twofold increase in lactate production in chicken Sertoli cell cultures, but the lactate level remained unchanged in the whole testis in vivo. The discrepancy in results obtained in vitro and in vivo could be due to the time of exposure, the presence of several other cell types in the testis (Leydig, peritubular and germ cells), the presence of glucose and other factors involved in the Sertoli cell microenvironment that can modify the effects of metformin in comparison to Sertoli cell culture in vitro. Nonetheless, these results are concordant with previous experiments carried out on rat Sertoli cells with 50 and $500 \mu \mathrm{M}$ metformin which have shown an increase in lactate and acetate secretion (Alves et al. 2014). Testosterone levels were also reduced by $50 \%$ after metformin administration in vivo. Testosterone is known to be crucial for spermatogenesis. These results are concordant with those obtained in mammals (Tartarin et al. 2012a), suggesting a conservation of this mechanism 

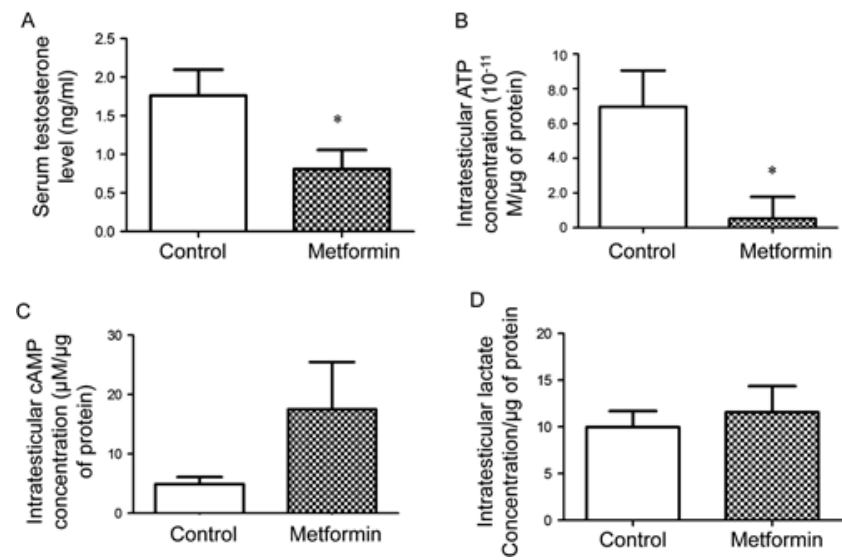

Figure 7 Consequences of metformin administration on testis functions. (A) Serum testosterone concentrations ( $n=8$ animals/ condition) were measured in controls and after 3 weeks of metformin treatment. (B) ATP, (C) CAMP and (D) lactate concentrations were measured in testis chickens treated or not with metformin $(n=6$ testes/condition). ${ }^{*} P<0.05$.

in birds. Interestingly, activation of the AMPK pathway by another pharmacological drug (AICAR) in rat Sertoli cells stimulated lactate production (Galardo et al. 2007). Under our conditions, the lactate production could be due to the role of metformin in inhibiting the respiratory chain complex 1, blocking mitochondrial activity (Leverve et al. 2003) and promoting anaerobic respiration (Rena et al. 2013). Bertoldo et al. (2014a) remarked that mitochondrial activity of mouse spermatozoa is reduced after metformin incubation. Indeed, insulin increases lactate and transferrin production and glucose transport in rodent Sertoli cell cultures (Borland et al. 1984, Oonk et al. 1989). As metformin is known to sensitise tissue to insulin and stimulate glucose transport, we cannot exclude an effect through insulin.

Furthermore, we measured the effects of metformin on testosterone levels as others studies have reported an inhibition in steroid production by metformin. Metformin exposure of human and mouse testes cultured in vitro caused a reduction in testosterone secretion associated with a decrease in the expression of different enzymes involved in testosterone biosynthesis. In primary rat Leydig cell culture, the use of a natural AMPK ligand (curcumin; Zang et al. 2006) decreases testosterone secretion through a reduction in cholesterol transport into the mitochondria and decreased conversion of progesterone into androstenedione (Svechnikov et al. 2009). In females, metformin reduced progesterone and oestradiol $\left(E_{2}\right)$ secretion by bovine granulosa cells, via downregulation of proteins involved in steroid production (Tosca et al. 2006), and metformin reduced aromatase activity in human granulosa cells (Rice et al. 2009). In our model, the decrease in serum testosterone levels was not associated with the overall growth rate of the treated birds, despite that testosterone is associated with muscle development and growth rate (Bhasin et al. 2001).

Moreover, we observed an effect of metformin on the germ cell population in culture and in vivo, suggesting a direct effect on germ cells. There was a significant reduction in testis weight, associated with a decrease in the diameter of seminiferous tubules and in the testicular content of the protamine spermatid marker. The absence of alterations in the immature germ cell marker content (DAZL) after metformin exposure was associated with a reduction in protamine content, suggesting an effect on sperm production or in the maturation process during meiosis. This hypothesis is supported by the in vitro data showing a decrease in the percentage of BrdU-positive $\mathrm{cVH}$ cells after metformin treatment. Similar observations have been reported in female germ cells. The maturation of bovine and porcine oocytes in vitro was inhibited in the presence of metformin (Tosca et al. 2007, BilodeauGoeseels et al. 2014). The decrease in protamine content could be associated with a decrease in testosterone. Indeed, germ cells receive the androgen signal through
A
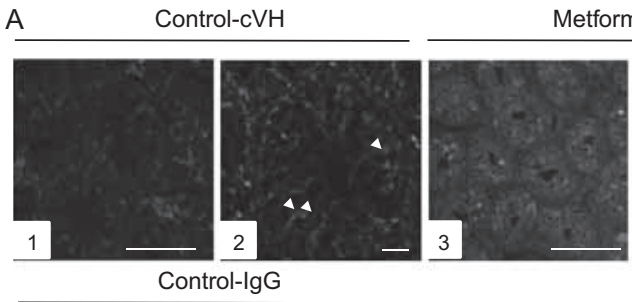

Metformin-cVH

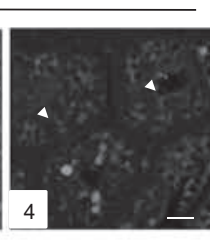

B

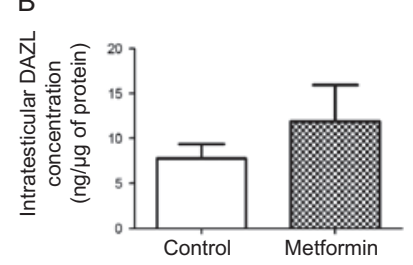

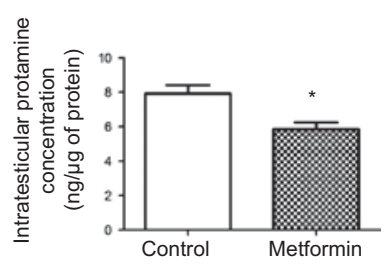

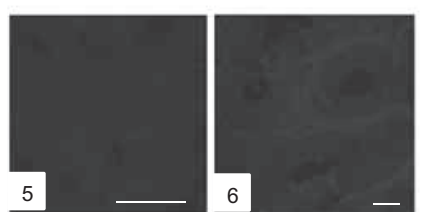

Figure 8 Consequences of metformin administration on germ cell populations. (A) Immunohistochemistry of cVH on untreated testis ( 1 and 2 ) or after metformin treatment (3 and 4). IGG was used as the control (5 and 6): Scale bar (1, 3 and 5)=100 $\mu \mathrm{m}$ and scale bar $(2,4$ and 6$)=20 \mu \mathrm{m}$. (B) Testicular content of the spermatogonia marker (DAZL, $n=6$ testes/condition) and (C) spermatid marker (protamine, $n=5$ testes/condition), from untreated or metformin-exposed chicken. DAZL is expressed in spermatogonia and immature germ cells, and protamine is expressed in spermatids and differentiated germ cells. ${ }^{*} P<0.05$. 
Sertoli cells that possess androgen receptors. Full spermatogenesis is dependent on adequate serum testosterone levels, explaining why the specific invalidation of the androgen receptor in mouse Sertoli cells induces perturbed spermatogenesis, and is evidence that androgens act through Sertoli cells during male germ cell development (De Gendt et al. 2004). These observations could also be linked to a study (Ibanez et al. 2006) using metformin to delay precocious puberty in humans.

Metformin may induce different effects depending on the age, stage of development, the metabolic status (insulin resistant or not), the species, dose and method of administration of the insulin sensitiser. Thus, there is data indicating that metformin administration in adult obese rats fed high-fat diet restores reproductive parameters (testosterone, $\mathrm{E}_{2}$, semen quality and testis weight; Yan et al. 2015). In addition, there is a recent report of an increase in the percentage of intersex fish after metformin exposure during developmental stages at environmental doses, without clear effects on testosterone levels and gonad appearance (Niemuth et al. 2015). These data are complemented by those of Tartarin et al. (2012a), who observed decreased testosterone production in vitro and decreases in testis size in mice exposed to metformin during foetal development of animals unaffected by type 2 diabetes.

Based on the present results described in this study, we cannot exclude the effects from other organs, such as the hypothalamic-pituitary-axis (Fernandez-Fernandez et al. 2006, Bertoldo et al. 2014b). Indeed, in several species, including birds, lower luteinising hormone (LH) levels correlated with testis growth, testosterone levels and delays in puberty (Sedqyar et al. 2008). In rat pituitary gonadotrope cells, metformin has been described to inhibit $\mathrm{LH}$ and FSH secretion induced by gonadotrophin-releasing hormone (GNRH; Tosca et al. 2011). In immortalised murine GNRH hypothalamic neurones, metformin increased the activation of AMPK $\alpha$ and inhibited the GNRH release (Coyral-Castel et al. 2008), which could reduce gonadotrophin release.

The AMPK signalling pathway is described as one of the known targets of metformin. Previous studies on rat and mice demonstrated the presence of AMPK in testis (Cheung et al. 2000, Galardo et al. 2007, Tartarin et al. $2012 b)$. In the chicken testis, both AMPK $\alpha, A M P K \beta$ and the AMPK 1 subunit were localised in the seminiferous tubules. Our results are in concordance with those of Cheung et al. (2000) who detected higher concentrations of AMPK $\gamma 1$ subunits and less AMPK $\gamma 3$ in rat testes. These results may be explained by the testis volume that $90-95 \%$ of which is occupied by seminiferous tubules and only $5-10 \%$ by Leydig cells (De Reviers 1971, Cheung et al. 2000). The PI3K and ERK pathways that play a role in the testicular signalisation did not seem to be modulated after metformin exposure in Sertoli cells in vitro.

In conclusion, the in vitro and in vivo approaches used in this study have shown that metformin significantly reduces the proliferation of somatic and germ cells and modulates the metabolism and the secretory activities of the chicken Sertoli cells. Further evaluating the effects of metformin in terms of semen quality and the fertility of mature birds would be an interesting avenue of future research.

\section{Supplementary data}

This is linked to the online version of the paper at http://dx.doi. org/10.1530/REP-15-0565.

\section{Declaration of interest}

The authors declare that there is no conflict of interest that could be perceived as prejudicing the impartiality of the research reported.

\section{Funding}

This work was supported by the National Institute of Agronomic Research (INRA) and by Region Centre - Val de Loire for PhD fellowship.

\section{Acknowledgements}

The authors thank Jean-Marie Brigant, Olivier Callut, Patrice Garnier and Frederic Mercerand for expert animal care. They thank Anne-Lyse Laine for testosterone assays and Yves Le Vern for flow cytometry analyses. They express their gratefulness to Daniele Carré-Eusèbe, Emmanuelle Oréal, Jean-Yves Picard (Paris, France) for generously providing the chAMH antibody. They wish to thank Drs Severine Mazaud-Guittot and Michael Bertoldo for review of the manuscript.

\section{References}

Alimova IN, Liu B, Fan Z, Edgerton SM, Dillon T, Lind SE \& Thor AD 2014 Metformin inhibits breast cancer cell growth, colony formation and induces cell cycle arrest in vitro. Cell Cycle 8 909-915. (doi:10.4161/ cc.8.6.7933)

Alves MG, Martins AD, Vaz CV, Correia S, Moreira PI, Oliveira PF \& Socorro S 2014 Metformin and male reproduction: effects on Sertoli cell metabolism. British Journal of Pharmacology 171 1033-1042. (doi:10.1111/bph.12522)

Bertoldo MJ, Guibert E, Tartarin P, Guillory V \& Froment P 2014a Effect of metformin on the fertilizing ability of mouse spermatozoa. Cryobiology 68 262-268. (doi:10.1016/j.cryobiol.2014.02.006)

Bertoldo MJ, Faure M, Dupont J \& Froment P $2014 b$ Impact of metformin on reproductive tissues : an overview from gametogenesis to gestation. Annals of Translational Medicine 2 1-13. (doi:10.1016/j. mce.2016.01.001)

Bhasin S, Woodhouse L \& Storer TW 2001 Proof of the effect of testosterone on skeletal muscle. Journal of Endocrinology 170 27-38. (doi:10.1111/jgs.2008.56.issue-11)

Bilodeau-Goeseels S, Magyara N \& Collignon C 2014 Characterization of the effects of metformin on porcine oocyte meiosis and on AMPactivated protein kinase activation in oocytes and cumulus cells. Zygote 22 275-85. (doi:10.1017/S0967199413000075)

Blomqvist A, Berg C, Holm L, Brandt I, Ridderstrale Y \& Brunstrom B 2006 Defective reproductive organ morphology and function in domestic rooster embryonically exposed to o-p'-DDT or ethynylestradiol. Biology of Reproduction 74 481-486. (doi:10.1897/05-619R.1) 
Borland K, Mita M, Oppenheimer CL, Blinderman LA, Massague J, Hall PF \& Czech MP 1984 The actions of insulin-like growth factors I and || on cultured Sertoli cells. Endocrinology 114 240-246. (doi:10.1210/endo-114-1-240)

Brillard JP \& De Reviers M 1981 Testis development and daily sperm output in guinea-fowl raised under constant daily photoperiods. Reproduction, Nutrition, Développement 21 1105-1112. (doi:10.1051/rnd:19810809)

Buzzai M, Jones RG, Amaravadi RK, Lum JJ, DeBerardinis RJ, Zhao F, Viollet B \& Thompson CB 2007 Systemic treatment with the antidiabetic drug metformin selectively impairs p53-deficient tumor cell growth. Cancer Research 67 6745-6752. (doi:10.1158/0008-5472.CAN-06-4447)

Chen W-L, Wei H-W, Chiu W-Z, Kang C-H, Lin T-H, Hung C-C, Chen MC, Shieh M-S, Lee C-C \& Lee H-M 2011 Metformin regulates hepatic lipid metabolism through activating AMP-activated protein kinase and inducing ATGL in laying hens. European Journal of Pharmacology $\mathbf{6 7 1}$ 107-112. (doi:10.1016/j.ejphar.2011.09.029)

Cheung PCF, Salt IP, Davies SP, Hardie DG \& Carling D 2000 their role in AMP binding. Biochemistry 346 659-669. (doi:10.1042/bj3460659)

Chou SH-H \& Mantzoros C 2014 Leptin in human reproductive disorders. Journal of Endocrinology 223 T49-T62.

Coyral-Castel S, Tosca L, Ferreira G, Jeanpierre E, Rame C, Lomet D, Caraty A, Monget P, Chabrolle C \& Dupont J 2008 The effect of AMPactivated kinase activation on gonadotrophin-releasing hormone secretion in GT1-7 cells and its potential role in hypothalamic regulation of the oestrous cyclicity in rats. Journal of Neuroendocrinology 20335 346. (doi:10.1111/jne.2008.20.issue-3)

Crepieux P, Marion S, Martinat N, Fafeur V, Vern YL, Kerboeuf D, Guillou F \& Reiter E 2001 The ERK-dependent signalling is stagespecifically modulated by FSH, during primary Sertoli cell maturation. Oncogene 20 4696-4709. (doi:10.1038/sj.onc.1204632)

De Reviers M 1971 Le developpement testiculaire chez le coq. Annales de biologie animale, biochimie, biophysique 11 519-530. (doi:10.1051/ rnd:19710401)

De Reviers M, Hochereau-de Reviers MT, Blanc MR, Brillard JP, Courot M \& Pelletier J 1980 Control of Sertoli and germ cell populations in the cock and sheep testes. Reproduction, Nutrition, De'veloppement 20 241-9. (doi:10.1051/rnd:19800206)

Djakiew D \& Dym M 1988 Pachytene spermatocyte protein influence Sertoli cell function. Biological Research for Nursing 39 1193-1205. (doi:10.1158/1541-7786.MCR-10-0342)

Dupont J, Métayer-Coustard S, Ji B, Ramé C, Gespach C, Voy B \& Simon J 2012 Characterization of major elements of insulin signaling cascade in chicken adipose tissue: apparent insulin refractoriness. General and Comparative Endocrinology 176 86-93. (doi:10.1016/j. ygcen.2011.12.030)

Fernandez-Fernandez R, Martini AC, Navarro VM, Castellano JM, Dieguez C, Aguilar E, Pinilla L \& Tena-Sempere M 2006 Novel signals for the integration of energy balance and reproduction. Molecular and Cellular Endocrinology 254-255 127-132. (doi:10.1016/j. mce.2006.04.026)

Franks S, Robinson S \& Willis DS 1996 Nutrition, insulin and polycystic ovary syndrome. Reviews of Reproduction 1 47-53. (doi:10.1046/ j.1365-2265.2000.01123.x)

Froment P, Staub C, Hembert S, Pisselet C, Magistrini M, Delaleu B, Seurin D, Levine JE, Johnson L, Binoux M et al. 2004 Reproductive abnormalities in human insulin-like growth factor-binding protein-1 transgenic male mice. Endocrinology 145 2080-2091. (doi:10.1210/ en.2003-0956)

Froment P, Dupont J \& Christophe-Marine J 2008 Mdm2 exerts proapoptotic activities by antagonizing insulin-like growth factor-I-mediated survival. Cell Cycle 7 3098-3103. (doi:10.4161/cc.7.19.6807)

De Gendt K 2004 A Sertoli cell-selective knockout of the androgen receptor causes spermatogenic arrest in meiosis. PNAS 101 1327-1332. (doi:10.1073/pnas.0308114100)

Galardo MN, Riera MF, Pellizzari EH, Cigorraga SB \& Meroni SB 2007 The AMP-activated protein kinase activator, 5-aminoimidazole-4carboxamide-1-b-d-ribonucleoside, regulates lactate production in rat Sertoli cells. Journal of Molecular Endocrinology 39 279-288. (doi:10.1016/j.ygcen.2015.08.011)

Guibert E, Brière S, Pelletier R, Brillard JP \& Froment P 2011 Characterization of chicken Sertoli cells in vitro. Poultry Science $\mathbf{9 0}$ 1276-1286. (doi:10.3382/ps.2010-01081)
Guibert E, Prieur B, Cariou R, Courant F, Antignac JP, Pain B, Brillard JP \& Froment P 2013 Effects of mono-(2-ethylhexyl) phthalate (MEHP) on chicken germ cells cultured in vitro. Environmental Science and Pollution Research International 20 2771-2783. (doi:10.1007/s11356013-1487-2)

Havenstein GB, Ferket PR \& Qureshi MA 2003 Growth, livability, and feed conversion of 1957 versus 2001 broilers when fed representative 1957 and 2001 broiler diets. Poultry Science 82 1500-1508. (doi:10.1093/ $\mathrm{ps} / 86.2 .241)$

Hochereau-de Reviers MT, Perreau C, Pisselet C, Fontaine I \& Monet-Kuntz C 1990 Comparisons of endocrinological and testis parameters in 18-month-old lle de France and Romanov rams. Domestic Animal Endocrinology 7 63-73. (doi:10.1677/joe.0.1310101)

Hocking PM 1987 Nutritional interactions with reproduction in birds. Proceedings of the Nutrition Society 46 217-225. (doi:10.1079/ PNS19870029)

Holsberger DR, Buchold GM, Leal MC, Kiesewetter SE, O'Brien DA Hess RA, França LR, Kiyokawa H \& Cooke PS 2005 Cell-cycle inhibitors p27Kip1 and p21Cip1 regulate murine Sertoli cell proliferation. Biology of Reproduction 72 1429-1436. (doi:10.1095/biolreprod.105.040386)

Ibáñez L, Ong K, Valls C, Marcos MV, Dunger DB \& de Zegher F (2006) Metformin treatment to prevent early puberty in girls with precocious pubarche. Journal of Clinical Endocrinology and Metabolism 912888 2891. (doi:10.1210/jc.2006-0336)

Ji B, Ernest B, Gooding JR, Das S, Saxton AM, Simon J, Dupont J, Métayer-Coustard S, Campagna SR \& Voy BH 2012 Transcriptomic and metabolomic profiling of chicken adipose tissue in response to insulin neutralization and fasting. BMC Genomics 13 441. (doi:10.1186/14712164-13-441)

Ji B, Middleton JL, Ernest B, Saxton AM, Lamont SJ, Campagna SR \& Voy BH 2014 Molecular and metabolic profiles suggest that increased lipid catabolism in adipose tissue contributes to leanness in domestic chickens. Physiological Genomics 46 315-327. (doi:10.1152/ physiolgenomics.00163.2013)

Jutte NH, Grootegoed JA, Rommerts FFG \& van der Molen HJ 1981 Exogenous lactate is essential for metabolic activities in isolated rat spermatocytes and spermatids. Journal of Reproduction and Fertility $\mathbf{6 2}$ 399-405. (doi:10.1530/jrf.0.0620399)

Khan SA, Ndjountche L, Pratchard L, Spicer LJ \& Davis JS 2002 Folliclestimulating hormone amplifies insulin-like growth factor I-mediated activation of AKT/protein kinase B signaling in immature rat Sertoli cells. Endocrinology 143 2259-2267. (doi:10.1210/endo.143.6.8838)

Lavial F, Acloque H, Bachelard E, Nieto MA, Samarut J \& Pain B 2009 Ectopic expression of Cvh (chicken Vasa homologue) mediates the reprogramming of chicken embryonic stem cells to a germ cell fate. Developmental Biology 330 73-82. (doi:10.1016/j.ydbio.2009.03.012)

Legendre A, Froment P, Desmots S, Lecomte A, Habert R \& Lemazurier E 2010 An engineered 3D blood-testis barrier model for the assessment of reproductive toxicity potential. Biomaterials 31 4492-4505. (doi:10.1016/j.biomaterials.2010.02.029)

Leverve XM, Guigas B, Detaille D, Batandier C, Koceir EA, Chauvin C, Fontaine E \& Wiernsperger NF 2003 Mitochondrial metabolism and type-2 diabetes: a specific target of metformin. Diabetes \& Metabolism 29 6S88-6S94.

Migliorini D, Denchi EL, Danovi D, Jochemsen A, Capillo M, Gobbi A, Helin K, Pelicci PG \& Marine J-C 2002 Mdm4 (Mdmx) regulates p53induced growth arrest and neuronal cell death during early embryonic mouse development. Molecular and Cellular Biology 22 5527-5538. (doi:10.1128/MCB.22.15.5527-5538.2002)

Nguyen TMD, Alves S, Grasseau I, Métayer-Coustard S, Praud C, Froment P \& Blesbois E 2014 Central role of 5'-AMP-activated protein kinase in chicken sperm functions. Biology of Reproduction 91 121. (doi:10.1095/ biolreprod.114.121855)

Niemuth NJ \& Klaper RD 2015 Emerging wastewater contaminant metformin causes intersex and reduced fecundity in fish. Chemosphere 135 38-45. (doi:10.1016/j.chemosphere.2015.03.060)

Oonk RB, Jansen R \& Grootegoed JA 1989 Differential effects of follicle stimulating hormone, insulin, and insulin-like growth factor I on hexose uptake and lactate production by rat Sertoli cells. Journal of Cellular Physiology 139 210-218. (doi:10.1002/(ISSN)1097-4652)

Pasquali R 2006 Obesity, fat distribution and infertility. Maturitas $54363-$ 371. (doi:10.1016/j.maturitas.2006.04.018) 
Petersen C \& Soder O 2006 The Sertoli cell - a hormonal target and 'super' nurse for germ cells that determines testicular size. Hormone Research 66 153-161. (doi:10.1159/000094142)

Pirke KM, Bofilias I, Spyra B, Langhammer H \& Pabst HW 1982 Capillary blood flow in the tests and testosterone secretion in the starved rat. Experientia 38 516-517. (doi:10.1007/BF01952671)

Rato L, Alves MG, Cavaco JE \& Oliveira PF 2014 High-energy diets: a threat for male fertility? Obesity Reviews 15 996-1007. (doi:10.1016/j. biocel.2015.07.001)

Rena G, Pearson ER \& Sakamoto K 2013 Molecular mechanism of action of metformin: old or new insights? Diabetologia 56 1898-1906. (doi:10.1007/s00125-013-2991-0)

Rengaraj D, Zheng YH, Kang KS, Park KJ, Lee BR, Lee SI, Choi JW \& Han JY 2010 Conserved expression pattern of chicken DAZL in primordial germ cells and germ-line cells. Theriogenology 74 765-776. (doi:10.1016/j. theriogenology.2010.04.001)

Rice S, Pellatt L, Ramanathan K, Whitehead SA \& Mason HD 2009 Metformin inhibits aromatase via an extracellular signal-regulated kinase-mediated pathway. Endocrinology 150 4794-4801. (doi:10.1210/en.2009-0540)

Schneider JE 2004 Energy balance and reproduction. Physiology \& Behavior 81 289-317. (doi:10.1016/j.physbeh.2004.02.007)

Sedqyar M, Weng Q, Watanabe G, Kandiel MM, Takahashi S, Suzuki AK, Taneda S \& Taya K 2008 Secretion of inhibin in male Japanese quail (Coturnix japonica) from one week of age to sexual maturity. Journal of Reproduction and Development 54 100-106. (doi:10.1262/ jrd.19155)

Staub C, Hue D, Nicolle JC, Perrard-Sapori MH, Segretain D \& Durand P 2000 The whole meiotic process can occur in vitro in untransformed rat spermatogenic cells. Experimental Cell Research 260 85-95. (doi:10.1006/excr.2000.4998)

Svechnikov K, Spatafora C, Svechnikova I, Tringali C \& Söder O 2009 Effects of resveratrol analogs on steroidogenesis and mitochondrial function in rat Leydig cells in vitro. Journal of Applied Toxicology 29 673-680. (doi:10.1002/jat.v29:8)

Tan KAL, Turner KJ, Saunders PTK, Verhoeven G, De Gendt K, Atanassova N \& Sharpe RM 2005 Androgen regulation of stage-dependent cyclin D2 expression in Sertoli cells suggests a role in modulating androgen action on spermatogenesis. Biology of Reproduction 72 1151-1160. (doi:10.1095/biolreprod.104.037689)

Tartarin P, Guibert E, Touré A, Ouiste C, Leclerc J, Sanz N, Brière S, Dacheux J-L, Delaleu B, McNeilly JR et al. 2012a Inactivation of AMPK $\alpha 1$ induces asthenozoospermia and alters spermatozoa morphology. Endocrinology 153 3468-3481. (doi:10.1210/en.2011-1911)
Tartarin P, Moison D, Guibert E, Dupont J, Habert R, Rouiller-Fabre V, Frydman N, Pozzi S, Frydman R, Lecureuil C et al. 2012b Metformin exposure affects human and mouse fetal testicular cells. Human Reproduction 27 3304-3314. (doi:10.1093/humrep/des264)

Tosca L, Crochet S, Ferré P, Foufelle F, Tesseraud S \& Dupont J 2006 AMPactivated protein kinase activation modulates progesterone secretion in granulosa cells from hen preovulatory follicles. Journal of Endocrinology 190 85-97. (doi:10.1677/joe.1.06828)

Tosca L, Uzbekova S, Chabrolle C \& Dupont J 2007 Possible role of 5'AMP-activated protein kinase in the metformin-mediated arrest of bovine oocytes at the germinal vesicle stage during in vitro maturation. Biology of Reproduction 77 452-465. (doi:10.1095/ biolreprod.107.060848)

Tosca L, Froment P, Rame C, McNeilly JR, McNeilly AS, Maillard V \& Dupont J 2011 Metformin decreases GnRH- and activininduced gonadotropin secretion in rat pituitary cells: potential involvement of adenosine $5^{\prime}$ monophosphate-activated protein kinase (PRKA). Biology of Reproduction 84 351-362. (doi:10.1095/ biolreprod.110.087023)

Tsunekawa N, Naito M, Sakai Y, Nishida T \& Noce T 2000 Isolation of chicken Vasa homolog gene and tracing the origin of primordial germ cells. Development 127 2741-2750.

Walzem RL \& Chen S 2014 Obesity-induced dysfunctions in female reproduction: lessons from birds and mammals 1-3. American Society for Advances in Nutrition 5 199-206. (doi:10.1016/j.anireprosci. 2016.02.002)

Yan W, Mu Y, Yu N, Yi T, Zhang Y, Pang X, Cheng D \& Yang J (2015) Protective effects of metformin on reproductive function in obese male rats induced by high-fat diet. Journal of Assisted Reproduction and Genetics 32 1097-1104. (doi:10.1007/s10815-015-0506-2)

Zang M, Xu S, Maitland-Toolan KA, Zuccollo A, Hou X, Jiang B, Wierzbicki M, Verbeuren TJ \& Cohen RA 2006 Polyphenols stimulate AMP-activated protein kinase, lower lipids, and inhibit accelerated atherosclerosis in diabetic LDL receptor-deficient mice. Diabetes 55 2180-2191. (doi:10.2337/db05-1188)

Received 30 November 2015

First decision 4 January 2016

Revised manuscript received 6 February 2016

Accepted 25 February 2016 